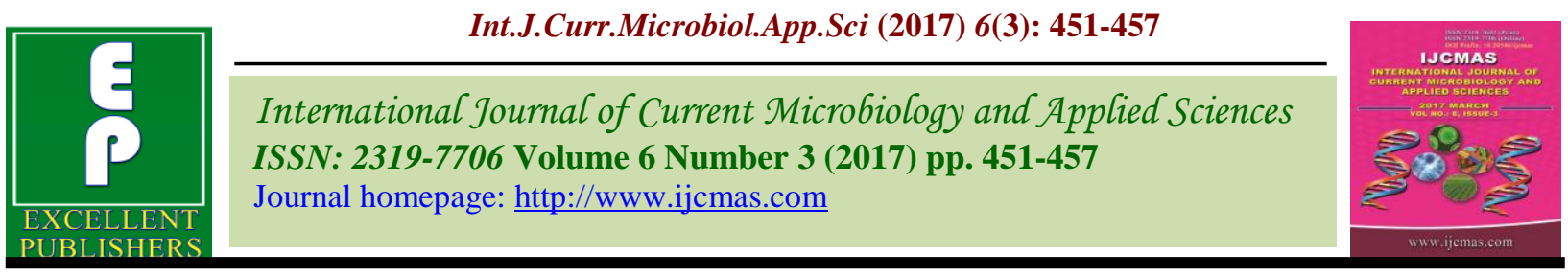

Original Research Article

https://doi.org/10.20546/ijcmas.2017.603.052

\title{
Impact of Nano-liming materials on Biological Properties of Acid Soils
}

\author{
C.H. Bhargava Rami Reddy ${ }^{*}$ and K.S. Subramanian \\ ${ }^{1}$ Department of Soil Science and Agricultural Chemistry, Tamil Nadu Agricultural University, \\ Coimbatore-641003, Tamil Nadu, India \\ ${ }^{2}$ Department of Nano Science and Technology, Tamil Nadu Agricultural University, \\ Coimbatore-641003, Tamil Nadu, India \\ *Corresponding author
}

\begin{tabular}{|c|c|}
\hline & A B S T R A C T \\
\hline $\begin{array}{l}\text { Ke y w o r d s } \\
\text { Nano-lime, Nano- } \\
\text { dolomite, Acidsoils, } \\
\text { Efficiency. }\end{array}$ & \multirow{3}{*}{$\begin{array}{l}\text { The nano-lime and nano-dolomite had the surface areas of } 1000 \text { and } 900 \mathrm{~m}^{2} \mathrm{~g}^{-1} \text {, } \\
\text { respectively, which are nearly } 10 \text { times higher than their respective conventional counter } \\
\text { parts. Nano-liming is more effective due to the extensive surface areas of these materials that } \\
\text { had increased by ten times which correspondingly increased the exchange properties. As a } \\
\text { result of eluviations of acidity producing cations, the Ca and } \mathrm{Mg} \text { added through the liming } \\
\text { materials got adsorbed that closely coincided with a set of favourable changes in soil properties. } \\
\text { The changes in soil properties had reflected on the yield and quality of crops grown in either } \\
\text { hilly or plain acidic soils. The data have unequivocally suggests that nano-liming may be one of } \\
\text { the plausible strategies to improve the liming efficiencies. There are several stages of testing of } \\
\text { the nano-materials for their biosafety prior to use in the open field conditions. It is one of the } \\
\text { early lead indicating improved liming efficiencies through nanotechnological approaches. }\end{array}$} \\
\hline Article Info & \\
\hline $\begin{array}{l}\text { Accepted: } \\
\text { 10 February } 2017 \\
\text { Available Online: } \\
10 \text { March } 2017\end{array}$ & \\
\hline
\end{tabular}

\section{Introduction}

Soil is a basic natural resource required for cultivation of crops and success of crop production primarily depends of its quality. Among the soil constrains, acidity is one of the major ones affecting one-third of arable lands in the country but the issue is least addressed.

Soil acidification is a slow natural process caused by the acids resulted from the weathering of parent materials. The rate of acidification is depending on the nature of the parent materials, effective rainfall and temperature. This is accelerated by the activities of plants, animals and humans. Globally, soil acidity is one of the most important factors affecting a wide array of crops grown under varied agro-climatic conditions. Acid soils $(\mathrm{pH}<5.5$ in surface layer) constitute 3,950 million ha or $30 \%$ of the world's total ice free land or about $40 \%$ of the arable land (Von Uexk"ull and Mutert, 1995).

The effectiveness of agricultural limestone also depends on the neutralizing value, physical properties and particle size (Brady and Weil, 2002). The rate of reaction of liming materials with acid soils depends upon its fineness because finer materials increase the surface contact with the soil. If the liming materials are coarse, the rate of reaction will be slight. The amount of finer fraction of liming 
materials will be required much less as compared to coarser fractions of the material to achieve a certain $\mathrm{pH}$.

In order to improve the liming efficiencies, nanotechnology may hold a promise as in exploits atom by atom manipulation and size reduction. The word "nano" refers to the size of one-billionth of a metre or one-millionth of a millimetre in any one of the dimension. We are aware that all materials are made up of atoms which are the smallest units and for example, ten atoms put together will measure one nanometer. As the size gets reduced, the surface area gets increased by several folds. For instance, a $5 \mathrm{~cm}^{3}$ has a surface area of 120 $\mathrm{cm}^{3}$ when the material is at its regular scale, if the same cube is divided 24 times to reach nano-dimension and the fractionated cube can be spread over a surface area equivalent to a football stadium. Such a phenomenal increase in surface to mass ratio makes nanotechnology very unique and powerful (Subramanian, 2013).

Due to adsorption by soil organic matter the mobility of nano-particles in the soil matrix is decreased and hence their influence on the microbial activities is drastically reduced. Hence, soil organic matter significantly influenced the fate of nano-particles in the environment. Generally, microorganisms present in soil interact with nano-particles through passive and active mechanisms resulting from changing microbial activities. Soil microorganisms are one of the ultimate recipients of nano-materials in the ecosystem and because of interaction with environment could be significantly affected when exposed to nano-materials.

\section{Materials and Methods}

\section{Source of raw material}

The sources of liming material such as calcite $\left(\mathrm{CaCO}_{3}\right)$ and dolomite $\left(\mathrm{CaCO}_{3} \quad \mathrm{MgCO}_{3}\right)$ conventional lime was purchased from $\mathrm{M} / \mathrm{s}$ Sigma Adrich Chemicals, Coimbatore. The nano-lime had a dimension of $115-120 \mathrm{~nm}$ in size and the Analar grade of lime was used for fortification.

\section{Ball milling}

High-Energy Ball Milling (HEBM) grinder (FRITSCH, Pulverisette 7, Germany) was used for the size reduction of lime and dolomite. Both adsorbents were powdered and passed through $<0.5 \mathrm{~mm}$ sieve and dried for a few hours at $60^{\circ} \mathrm{C}$.

Spheres of stainless steel balls were used for grinding the raw materials. Sample to stainless steel ball ratio adopted was for 1:10 (lime and dolomite). These samples were rotated at different speeds of 400, 450, 500 rpm for 1, 2, 4 and 6 hours in half cycle pause time of 15 minutes per 30 minutes interval (On - Off cycle) and quick dry technique was performed for size reduction (Ying et al., 1999; Amir et al., 2010).

\section{Synthesis}

Synthesis of nanoparticles was carried out by two methods viz., top down approach (physical synthesis) followed by stabilization of the materials using chitosan. Lime and dolomite were prepared and purified prior to the ball milling to achieve nano-dimension. The required quantity of lime as per the lime requirement (LR) was coated with the substrate (chitosan) to achieve the nano-lime. Accurately, $1 \mathrm{~g}$ of analar grade chitosan was dissolved in $100 \mathrm{ml}$ of acetic acid (1\% chitosan solution) and the solution was transferred to 2:1 ratio of chitosan solution and nano-lime or nano-dolomite. The slurry was spread on a metal tray and kept in hot air oven at $70^{\circ} \mathrm{C}$ for 2 to 3 days until the material reached state of dry powder. The dried sample of lime and dolomite was grinding and produced nano-lime and nano-dolomite 


\section{Biological properties}

\section{Microbial population}

Different kinds of microorganisms in large number are present in soil. The type of microorganism that predominantly present in soil depends on soil type, moisture, $\mathrm{pH}$ and other environmental factors. By single method it is impossible to count all microorganisms since such a great variability and type of organism present in soil. Therefore it is necessary to use different type of media for growth of microorganisms. Serial dilution technique and plating on nutrient media can be used to determine the number of viable microorganisms.

One gram of soil sample was taken in the $100 \mathrm{ml}$ water blank and shacked for 15 minutes for complete dispersion (This gives $10^{-2}$ dilution). One $\mathrm{ml}$ of the suspension was transferred to $9 \mathrm{ml}$ of water blank (This gives $10^{-3}$ dilution). Transferred serially up to $10^{-7}$ dilution, the dilution $10^{-7}$ or $10^{-8}$ was used for bacteria (nutrient agar), $10^{-3}$ or $10^{-4}$ for fungi (rose bengal agar) and $10^{-4}$ or $10^{-5}$ for actinomycetes (kenknight media). One $\mathrm{ml}$ of appropriate dilutions to petridishes, melted and cooled media of about $15 \mathrm{ml}$ was mixed well by shaking clockwise and anticlockwise for 3 or 4 times and allowed for complete solidification. The plates were incubated in inverted position at room temperature for 2-7 days. The bacterial colonies were enumerated after 2 days, fungi after 5 to 7 days and actinomycetes after 7 days.

\section{Results and Discussion}

A series of experiments were conducted to synthesize and characterise nano-lime and nano-dolomite under laboratory conditions. The nano-materials were compared with conventional forms of lime and dolomite on the reclamation of hilly and plain acid soils and that's response was studied using radish and greengram as test crops. The results related to its effect on reclamation of acidic soil, changes in soils $\mathrm{pH}$ and nutrient status, and soil microbial population. The data recorded were statistically analyzed and the results are presented in this chapter.

\section{Synthesis of liming materials}

Nano-materials were synthesized from the two raw materials such as conventional forms of lime and dolomite using ball milling (top down) approach. The particle size was reduced significantly with time and speed (revolution per minute). Lime particle dimensions at the initial, one, two, four and six hours of ball milling were 878, 475, 398, 257 and $121 \mathrm{~nm}$, respectively. Among the three speeds tested, $500 \mathrm{rpm}$ was found effective in achieving near-nano dimensions. The surface areas measured in the corresponding same set of particles measured were $41,55,72,83$ and $110 \mathrm{~m}^{2} \mathrm{~g}^{-1}$.

Similarly, the particle sizes of dolomite at the initial, one, two, four and six hours of ball milling were 940, 656, 420, 270 and $127 \mathrm{~nm}$, respectively, at $500 \mathrm{rpm}$. The surface areas of the same set of particles were 57, 76, 88, 96 and $101 \mathrm{~m}^{2} \mathrm{~g}^{-1}$, respectively. In order to stabilize the nano-particles, $1 \%$ chitosan was used to encapsulate the particles.

\section{Physico - chemical properties of nano-lime and nano-dolomite}

The physical and chemical properties of nanolime and nano-dolomite are furnished in table 1. The result indicated that nano-lime and nano-dolomite had the size $(100-120 \mathrm{~nm}, 100-$ $115 \mathrm{~nm}$ ), shape (trigonal), surface area (1000, $\left.900 \mathrm{~m}^{2} \mathrm{~g}^{-1}\right)$, and bulk density $(0.45,0.48 \mathrm{Mg}$ $\mathrm{m}^{-3}$ ). The colour of the nano-lime and nanodolomite were measured using Munsell colour chart. The results showed that nano-lime is 
dusty white in colour (5Y 8/1) whereas the colour of the nano-dolomite was light gray in colour (2.5 Y8/1).

The $\mathrm{pH}$ of the nano-lime and nano-dolomite were 12.30 and 8.40, respectively. The electrical conductivity (EC) of the nano-lime was $0.02 \mathrm{dSm}^{-1}$, while the nano-dolomite had $0.03 \mathrm{dS} \mathrm{m}^{-1}$. The CEC of the nano-lime and nano-dolomite were comparable $(189 ; 187 \mathrm{c}$ mol $\left.\left(\mathrm{p}^{+}\right) \mathrm{kg}^{-1}\right)$.

\section{Characterization}

\section{Particle size distribution}

Particle size distribution of conventional forms of lime and dolomite were in the range of 750 to $896 \mathrm{~nm}$ and the average PSDs of lime and dolomite single peaks were exhibited at $896 \mathrm{~nm}$. After ball milling, the sizes of the lime and dolomite were reduced to 101 - $102 \mathrm{~nm}$. After encapsulation of nanolime and nano-dolomite with chitosan the size increased up to $115 \mathrm{~nm}$ and $119 \mathrm{~nm}$, respectively (Table 2 and Fig. 1a-f).

\section{Zeta potential}

The zeta potential was characterized using zeta analyzer which showed that the conventional lime, conventional dolomite had $-6 \mathrm{mV}$ and $-4 \mathrm{mV}$ zeta potentials. After encapsulation with chitosan, the encapsulated nano-lime, encapsulated nano-dolomite had zeta potentials of -50.9 and $-49.4 \mathrm{mV}$, respectively (Table 2 and Fig. 2).

Table.1 Physico-chemical properties of nano-lime and nano-dolomite

\begin{tabular}{|l|c|c|}
\hline \multicolumn{1}{|c|}{ Parameters } & Nano-lime & Nano-dolomite \\
\hline Physical Properties & $100-120 \mathrm{~nm}$ & $100-115 \mathrm{~nm}$ \\
\hline Size $(\mathrm{nm})$ & Trigonal & Trigonal \\
\hline Shape & 1000 & 900 \\
\hline Surface Area $\left(\mathrm{m}^{2} \mathrm{~g}^{-1}\right)$ & 0.45 & 0.48 \\
\hline Density $\left(\mathrm{Mg} \mathrm{m}^{-3}\right)$ & $5 \mathrm{Y} 8 / 1$ & $2.5 \mathrm{Y} 8 / 1$ \\
\hline Color & & 8.40 \\
\hline Chemical Properties & 12.30 & 0.03 \\
\hline $\mathrm{pH}$ & 0.02 & 189 \\
\hline EC $\left(\mathrm{dSm} \mathrm{Sm}^{-1}\right)$ & 187 & \\
\hline CEC $\left(\mathrm{C} \mathrm{mol}^{+} \mathrm{p}^{+} \mathrm{kg}^{-1}\right)$ & & \\
\hline
\end{tabular}

Table.2 Particle size and zeta potential of liming materials

\begin{tabular}{|l|c|c|}
\hline \multicolumn{1}{|c|}{ Forms } & Particle size & Zeta potential \\
\hline Lime & $896 \mathrm{~nm}$ & $-6 \mathrm{mV}$ \\
\hline Conventional lime & $102 \mathrm{~nm}$ & $-23.7 \mathrm{mV}$ \\
\hline Nano-lime & $115 \mathrm{~nm}$ & -50.9 \\
\hline Encapsulated nano-lime & & $-4 \mathrm{mV}$ \\
\hline Dolomite & $750 \mathrm{~nm}$ & $-21.2 \mathrm{mV}$ \\
\hline Conventional dolomite & $101 \mathrm{~nm}$ & $-49.4 \mathrm{mV}$ \\
\hline Nano-dolomite & $119 \mathrm{~nm}$ & \\
\hline Encapsulated nano-dolomite &
\end{tabular}


Table.3 Liming materials effect on microbial population

\begin{tabular}{|c|c|c|c|c|c|c|c|c|c|}
\hline Treatments & \multicolumn{3}{|c|}{$\operatorname{Bacteria}\left(10^{6}\right)$} & \multicolumn{3}{|c|}{ Fungi $\left(10^{4}\right)$} & \multicolumn{3}{|c|}{ Actinomycetes $\left(10^{3}\right)$} \\
\hline Lime (S) & $\begin{array}{c}\text { Conv } \\
\text { (F) }\end{array}$ & $\operatorname{Nano}(F)$ & Mean & Conv $(\mathbf{F})$ & $\operatorname{Nano}(F)$ & Mean & Conv (F) & $\begin{array}{l}\text { Nano } \\
\text { (F) }\end{array}$ & Mean \\
\hline LO Control & 41 & 41 & 41 & 30 & 30 & 30 & 14 & 14 & 14 \\
\hline L1 $25 \%$ & 44 & 47 & 45 & 33 & 41 & 37 & 16 & 20 & 18 \\
\hline L2 $50 \%$ & 47 & 51 & 49 & 35 & 43 & 39 & 19 & 21 & 20 \\
\hline L3 75\% & 50 & 55 & 52 & 40 & 45 & 43 & 22 & 23 & 22 \\
\hline L4 $100 \%$ & 52 & 55 & 53 & 44 & 48 & 46 & 24 & 26 & 25 \\
\hline Mean & 46 & 49 & 48 & 36 & 41 & 39 & 19 & 20 & 19 \\
\hline \begin{tabular}{|l} 
Dolomite (S) \\
Dole
\end{tabular} & & & & & & & & & \\
\hline D0 Control & 41 & 41 & 41 & 30 & 30 & 30 & 14 & 14 & 14 \\
\hline D1 25\% & 41 & 45 & 43 & 30 & 37 & 33 & 14 & 18 & 16 \\
\hline D2 50\% & 43 & 49 & 46 & 33 & 41 & 37 & 16 & 20 & 18 \\
\hline D375\% & 47 & 53 & 50 & 37 & 43 & 40 & 19 & 24 & 21 \\
\hline D4 $100 \%$ & 48 & 54 & 51 & 42 & 43 & 42 & 20 & 24 & 22 \\
\hline Mean & 44 & 48 & 46 & 34 & 38 & 36 & 16 & 20 & 18 \\
\hline Total Mean & 45 & 49 & 47 & 35 & 40 & 38 & 18 & 20 & 19 \\
\hline & SEd & CD (5\%) & & SEd & $\begin{array}{l}\text { CD } \\
(5 \%)\end{array}$ & & SEd & $\begin{array}{l}\text { CD } \\
(5 \%)\end{array}$ & \\
\hline $\mathbf{S}$ & 0.24 & 0.48 & & 0.21 & 0.43 & & 0.27 & 0.54 & \\
\hline $\mathbf{F}$ & 0.24 & 0.48 & & 0.21 & 0.43 & & 0.27 & 0.54 & \\
\hline $\mathbf{L}$ & 0.38 & 0.76 & & 0.34 & 0.68 & & 0.42 & 0.86 & \\
\hline SXF & 0.34 & 0.68 & & 0.30 & 0.61 & & 0.38 & 0.77 & \\
\hline SXL & 0.53 & 1.08 & & 0.48 & 0.96 & & 0.60 & 1.21 & \\
\hline FXL & 0.53 & 1.08 & & 0.48 & 0.96 & & 0.60 & 1.21 & \\
\hline SXFXL & 0.75 & 1.52 & & 0.67 & 1.36 & & 0.85 & 1.72 & \\
\hline
\end{tabular}




\section{Soil microbial population}

Soil microbial population enumerated at the harvest stage showed a phenomenal increase in bacteria, fungi and actinomycetes with incremental levels of lime and dolomite application in both conventional and nanoformulations. The highest number of microbial colonies was registered at $\mathrm{L} 4$ applied in the form of nano-lime formulation at $48 \times 10^{4} ; 55 \times 10^{6}$ and $26 \times 10^{3}$ for fungi, bacteria and actinomycetes as fallowed by D4 in the form of nano-dolomite $48 \times 10^{4}$, $54 \times 10^{6}$ and $24 \times 10^{3}$, respectively. The values for the $\mathrm{L} 4$ conventional lime were 44 $\times 10^{4} ; 52 \times 10^{6} ; 24 \times 10^{3}$ and the values for D4 conventional dolomite were $42 \times 10^{4} ; 48$ $\times 10^{6}$ and $20 \times 10^{3}$ indicating a significantly lower value. Higher biological activities in nano-formulations application in comparison to conventional formulation were observed (Table 3 ).

Overall, the data have clearly indicated that nano-forms of lime or dolomite is found to possess extensive surface area which facilitates faster exchange of $\mathrm{H}+$ with $\mathrm{Ca}^{2+}$ and $\mathrm{Mg}^{2+}$. This cation exchange assisted in increasing $\mathrm{pH}$ of the amended soil up to 6.3 to 6.6 , while conventional forms of liming increased the soil $\mathrm{pH}$ up to 6.1. Nano-limed soils had long-lasting liming effects for about 30 days while conventional liming had effects only for 15 days. Such effect was attributed to its small particle size and higher surface area that assisted in retaining and releasing of exchangeable cations $\left(\mathrm{Ca}^{2+}\right.$ and $\left.\mathrm{Mg}^{2+}\right)$ for an extended period in comparison to conventional amendments. As a result of long-lasting liming effects, nano-liming helped to main soil $\mathrm{pH}$ close to neutral and majority of the macro and secondary nutrients were available plenty. The favourable $\mathrm{pH}$ and improved availability of nutrients in soil besides higher uptake of nutrients by plants had eventually resulted in higher yields of radish and greengram in nano-liming amended soils of hilly and plain regions. The data suggest the nano-forms liming materials have the potentials to improve the liming efficiency and improve the productivity of acid soils.

This study concludes that in order to determine the biosafety of the nano-liming materials, microbial activities were determined in the amended soils. The highest number of microbial colonies was registered at L4 applied in the form of nano-lime formulation at $48 \times 10^{4} ; 55 \times 10^{6}$ and $26 \times 10^{3}$ for fungi, bacteria and actinomycetes as fallowed by D4 in the form of nanodolomite $48 \times 10^{4} ; \quad 54 \times 10^{6}$ and $24 \times 10^{3}$ respectively. The values for the L4 conventional lime were $44 \times 10^{4} ; 52 \times 10^{6}$ and $24 \times 10^{3}$ and the values for D4 conventional dolomite were $42 \times 10^{4} ; 48 \times 10^{6}$; and $20 \times 10^{3}$ indicating significantly lower values.

Overall, the results suggest that nano-forms of liming materials are more efficient in reducing the acidity while improving the fertility of the soil in comparison to conventional forms. Such improvements are primarily attributed to the liming efficiency as a result of enhanced solubility and faster exchange of ions in the clay complex. More research is needed to test the biosafety of the materials and to validate the data of this study under open field conditions.

\section{References}

Anderson, N.P., J.M. Hart, D.M. Sullivan, N.W. Christensen, D.A. Horneck and G.J. Pirelli. 2013. Applying lime to raise soil $\mathrm{pH}$ for crop production (Western Oregon). Eastern Oregon Liming Guide, EM 9057.

Athanase, A., R. Vicky, M.N., Jayne and H. Sylvestre. 2013. Soil acidification and lime quality: sources of soil acidity, its effects on plant nutrients, efficiency of 
lime and liming requirements. Agricultural Advan., 2(9): 259-269.

Biswas, T.D. and S.K. Mukherjee. 2013. Textbook of Soil Science. Tata McGrawHill Publishing Company Limited, NewDelhi, 415.

Chimdi, A., H. Gebrekidan, K. Kibret and A. Tadesse. 2012. Effects of liming on acidity-related chemical properties of soils of different land use systems in Western Oromia, Ethiopia World J. Agric Sci., 8(6): 560-567.

DeRosa, M.C., C. Monreal, M. Schnitzer, R. Walsh and Y. Sultan. 2010. Nanotechnology in fertilizers. Nature Nanotechnol., 5: 540-547.

Gudu, S.O., P.O. Kisinyo, E.T. Makatiani, D.W. Odee, J.F.O. Esegu, S.A.O. Chamshama, C.O. Othieno, J.R. Okalebo, R.J. Osiyo and J.O. Owuoche. 2009. Screening of Sesbania for tolerance to aluminium toxicity and symbiotic effectiveness with acid tolerant rhizobia strains in Western Kenya acid soil. Expl. Agric., 45: 417-427.

Johnson, A. and M. Wood. 1990. DNA, a possible site of action of aluminum in Rhizobium sp. Appl. Environ. Microbial., 263: 502-504.

Kisinyo, 2012. Effects of lime, phosphorus and rhizobia on Sesbania sesban performance in a Western Kenyan acid soil. African J. of Agri. Res., 7(18): 2800-2809.

Lal, R. 2008. Soils and India's food security. $J$. Ind. Soc. Soil Sci., 56(2):129-138.

Manikandan, A. and Subramanian, K.S. 2014. Fabrication and characterisation of nanoporous zeolite based $\mathrm{N}$ fertilizer. African J. Agri. Res., 9(2): 276-284.

Mishra, V.K., Kumar, A. 2009. Impact of metal nanoparticles on plant growth promoting rhizobacteria. Dig. J. Nano mater. Bios., 4: 587-592.

Monreal, C.M. and M. Schnitzer. 2008. Soil organic matter in nano-composite and clay fractions, and soluble pools of the rhizosphere. 5th international symposium ISMOM, Pucón, Chile.

Moraru, C., I. Panchapakesan, P. Chithra and L. Kokini. 2007. Nanotechnology: A new frontier in food science. Food Tech., 5: 24-29.

Panse, V.G. and P.V. Sukathame. 1978. Statistical methods for agricultural workers. ICAR, New Delhi.

Sanginga, N., S.K.A. Danso, F. Zapata and B.G. Bowen. 1995. Phosphorus requirement and nitrogen accumulation by $\mathrm{N}_{2}$ fixing and non $\mathrm{N}_{2}$ fixing legume trees in low $\mathrm{P}$ soils. Biol. Fertil. Soils, 20: 205-221.

Santhosh Kumar, M. 2012. Synthesis and characterisation of nano-gypsum for effective remediation of sodic soil in rice (Oryza sativa L.). M.Sc. (Ag.) Thesis, Tamil Nadu Agricultural University, Coimbatore.

Subramanian, K.S. 2015. Nanotechnologies in Food and Agriculture. Springer International Publishing Switzerland DOI 10.1007/978-3-319-14024-7_3 pp.69-70.

Subramanian, K.S. and J.C. Tarafdar. 2011. Prospects of nanotechnology in Indian farming. Indian J. Agric. Sci., 81: 887893.

Wolkowski, R. and C. Laboski. 2011. Soil pH and crop response to lime source and tillage Proc. of the 2011 Wisconsin crop management conference, Vol. 50.

\section{How to cite this article:}

Bhargava Rami Reddy, C.H. and Subramanian, K.S. 2017. Impact of Nano-liming materials on Biological Properties of Acid Soils. Int.J.Curr.Microbiol.App.Sci. 6(3): 451-457. doi: https://doi.org/10.20546/ijcmas.2017.603.052 